\title{
PANDANGAN ULAMA KONSERVATIF DAN ULAMA PROGRESIF TENTANG TAFSIR AYAT LÂ IKRÂH FÎ AL-DÎN
}

\author{
Abd Moqsith \\ Universitas Islam Negeri Syarif Hidayatullah Jakarta, Indonesia \\ E-mail: moqsith@gmail.com
}

\begin{abstract}
The verse lâ ikrâh fî̀ al-dîn has been one of the most contested verses with regard to its meaning and definition by the 'ulama (religious scholars) from the past to the present. Basing on this verse, progressive 'ulama maintain that the idea of freedom of religion introduced by modern society does not contradict the Qur'ân. For them, freedom of religion includes not only freedom to convert to Islam, but also freedom to convert from Islam. This view is rejected by conservative 'ulama who argue that the meaning of the verse contains only freedom to convert to Islam, not to convert from Islam. If non-Muslims are free to convert to Islam, Muslims are not allowed to convert from Islam. Moreover, there are many 'Ulama who argue that the verse has been abrogated by other tens of verses which enjoin to fight against infidels and polytheists. After the revelation of 'verses of war' in the Qur'ân, the verse lâ ikrâh fî̀ al-dîn becomes no longer legally binding.
\end{abstract}

Keywords: Progressive 'Ulama, conservative 'ulama, nonMuslims, freedom of religion, verses of war.

\section{Pendahuluan}

Tidak ada ayat al-Qur'ân yang paling sering dikutip ketika bicara tentang kebebasan beragama dalam Islam selain ayat dalam QS. alBaqarah [2]: 256. Jika diterjemahkan, ayat itu akan berbunyi demikian, "Tidak ada paksaan dalam agama. Sungguh telah nyata (berbeda) kebenaran dan kesesatan. Karena itu, barangsiapa yang ingkar kepada tâghât dan beriman kepada Allah, sesungguhnya ia telah berpegang kepada tali yang amat kuat yang tidak akan putus. Allah Maha Mendengar dan Mendengar".

Bertumpu kepada pengertian leksikal ayat tersebut, tidak sedikit pemikir progresif Islam yang berkesimpulan bahwa Islam adalah agama yang mendukung penuh kebebasan beragama. Mereka 
menampik sekiranya Islam dianggap menegasikan ide kebebasan beragama.

Namun, pada saat yang sama, terdapat sekelompok ulama yang mengatakan bahwa ayat tersebut telah dihapuskan (naskb) pengertian dan hukumnya oleh ayat lain yang memerintahkan memerangi bahkan membunuh orang musyrik dan orang kafir. ${ }^{1}$ Pendapat ini misalnya dikemukakan Ibn Mas'ûd, Ibn Zayd, dan Sulaymân b. Mûsâ. Mereka berkata bahwa ayat di atas tidak boleh dibiarkan berdiri sendiri tanpa dikaitkan dengan ayat lain yang telah menganulir ayat di atas ${ }^{2}$, yaitu ayat "Ya ayyuhâ al-nabîy jâhid al-kuffâr wa al-munâfiqîn" (QS. alTahrîm [66]: 9). Bahkan tidak sedikit ulama yang secara kuantitatif menghitung bahwa ayat yang mendukung kebebasan beragama lebih sedikit ketimbang ayat yang menolak kebebasan beragama. Dengan demikian, ratusan ayat yang memerintahkan mengeksekusi orang musyrik dan kafir tidak bisa serta-merta dipatahkan oleh segelintir ayat yang hendak membiarkan orang musyrik dengan kemusyrikannya dan orang kafir dengan kekafirannya.

Sebagian yang lain mencoba mencari titik moderasi, bahwa ayat itu memang tidak dihapuskan. Hanya saja, ayat tersebut turun secara khusus untuk merespons orang-orang Ahli Kitab. Bahwa orang-orang Ahli Kitab tidak bisa dipaksa masuk ke dalam Islam selama mereka masih membayar pajak. ${ }^{3}$ Itu berarti orang non-Ahli Kitab seperti penyembah patung (ahl al-awthân) boleh dipaksa masuk Islam. Pendapat ini misalnya dikemukakan al-Sha'bî, Qatâdah, al-Ḥasan, dan al-Ḍaḥhâk. ${ }^{4}$ Pendapat ini didasarkan pada cerita Zayd b. Aslam yang dia dengar dari ayahandanya. Alkisah, sang ayah pernah mendengar 'Umar b. Khațâb berbicara kepada perempuan Kristen tua, "masuklah ke dalam Islam, maka engkau akan selamat, karena Allah telah mengutus Muhammad dengan membawa kebenaran". Lalu si

${ }^{1}$ Ibn al-'Arabî, Aḅkâm al-Qur'ân, Vol. 1 (Beirut: Dâr al-Fikr, t.th.), 310; Shihâb alDîn Maḥmûd b. 'Abd Allâh al-Husaynî al-Alûsî, Rûh al-Ma ânî fî Tafsîr al-Qur'ân alAžîm wa al-Sab' al-Mathânî, Vol. 2 (Kairo: Dâr al-Hadîth, 2005), 19; dan Nâṣir al-Dîn Abû Saî̀d 'Abd Allâh b. 'Umar b. Muhammad al-Shîrâzî al-Bayḍ̂awî, Anwâr al-Tanzîl wa Asrâr al-Ta’mîl, Vol. 1 (Beirut: Dâr al-Fikr, 1996), 557.

2 Abû 'Abd Allâh Muḥammad b. Aḥmad b. Abî Bakr al-Qurṭubî, al-jâmi li Aḅkâm al-Qur'ân, Vol. 2 (Kairo: Dâr al-Hadìth, 2002), 238.

3 'Alâ' al-Dîn al-Khâzin, Lubab al-Ta'wîl fì Ma'ânî al-Tanzîl, Vol. 1 (t.t.: Dâr al-Fikr, t.th.), 171; dan Muhammad al-Ṭ̂hhir b. 'Âshûr, al-Taḥ̂r wa al-Tanwîr, Vol. 3, dan Vol. 5 (Tunis: Dâr Suhnun li al-Nashr wa al-Tawzî‘, t.th.), 27.

${ }^{4}$ al-Alûsî, Rûh al-Ma ânî, Vol. 2, 19. 
perempuan menjawab, "saya sudah uzur-tua di mana kematian telah dekat" (anâ 'ajûr kabîrah wa al-mawt qarîb). Kemudian 'Umar berkata, "Ya Allah saksikanlah". Kemudian "Umar membaca "lâ ikrâh fî aldîn". 5

Menelusuri argumen para ulama itu cukup menarik. Bagaimana mereka bisa memunculkan kesimpulan berbeda? Bagaimana meletakkan beragam penafsiran tersebut dalam konteks sekarang terutama dalam konteks Indonesia yang plural? Adakah perbedaan warna penafsiran antara ulama klasik dan ulama kontemporer, ulama konservatif ${ }^{6}$ dan ulama progresif? ${ }^{7}$ Namun, sebelum itu, penting kiranya dikemukakan perihal sebab turun (sabab al-nu₹ûu) ayat tersebut. Dengan begitu akan segera disadari bahwa betapa beragamnya tafsir terhadap al-Qur'ân; satu ayat ditafsirkan secara berbeda-beda oleh para ulama.

\section{Ruang Historis Ayat Lâ Ikrâh fi al-Dîn}

Para ulama berkata bahwa mengetahui sabab al-nuðûl akan membantu seseorang untuk menemukan makna sebuah ayat dalam alQur'ân. Ibn Taymîyah dan al-Wâhịî bersepakat bahwa tidak mungkin seseorang mengetahui tafsir sebuah ayat tanpa mengetahui kisah dan sebab turunnya. ${ }^{8}$ Dalam kaitan itu, penting diketahui perihal sebab

${ }^{5}$ al-Qurțubî, al-Jâmi‘, Vol. 2, 238-239.

${ }^{6}$ Dalam Kamus Besar Bahasa Indonesia (KBBI), konservatif diartikan kolot, bersifat mempertahankan keadaan, kebiasaan, dan tradisi yang berlaku. Lihat Tim Penyusun Kamus Pusat Pembinaan, dan Pengembangan Bahasa, Kamus Besar Bahasa Indonesia (Jakarta: Balai Pustaka, 1996), 520. Dalam konteks sekarang, ulama konservatif identik dengan ulama yang hanya memelihara pendapat ulama terdahulu (almuhâfaz̧ah 'alâ al-qadîm al-sâlih), dan tidak berani menciptakan pendapat baru (al$a k h d h$ bi al-jadîd al-aslaḅ). Dengan perkataan lain, orientasi dan proyeksi ulama konservatif adalah ke masa lalu bukan ke masa depan.

7 Dalam Kamus Besar Bahasa Indonesia (KBBI), progresif diartikan dengan ke arah kemajuan, berhaluan ke arah perbaikan keadaan sekarang. Lihat Tim Penyusun Kamus Pusat Pembinaan, dan Pengembangan Bahasa, Kamus Besar Bahasa Indonesia, 790. Dengan demikian, ulama progresif bisa diartikan sebagai ulama yang punya orientasi dan proyeksi pemikiran ke masa depan bukan ke masa lalu seperti kecenderungan ulama konservatif. Nurcholish Madjid pernah menggunakan istilah "idea of progress" untuk menunjuk pada nilai-nilai kemajuan Islam. Lihat Nurcholish Madjid, Islam, Kemodernan, dan Keindonesiaan (Bandung: Mizan, 2008), 234.

8 Jalâl al-Dîn al-Suyûṭ̂, al-Itqân fî 'Ulûm al-Qur'ân, Vol. 1 (Kairo: Dâr al-Fikr, t.th.), 29. Tidak seluruh ayat dalam al-Qur'ân turun dengan sabab al-nu₹̂ul yang spesifik. Namun, bisa dipastikan bahwa seluruh ayat dalam al-Qur'ân turun dalam konteks 
yang melatari kehadiran ayat tersebut. Jika ditelusuri, ada beragam kisah yang menjadi sabab al-nuðûl ayat tersebut.'

Pertama, diriwayatkan Abû Dâwud dari Ibn 'Abbâs yang berkata bahwa ayat ini turun dalam kasus orang-orang Anșâr. Alkisah, terdapat seorang perempuan tidak punya anak berjanji pada dirinya bahwa sekiranya ia memiliki anak, maka si anak akan dijadikannya sebagai Yahudi. Maka turunlah ayat yang melarang pemaksaan tersebut. Bahkan, ketika orang-orang Yahudi Bani Nadhîr keluar dari Madinah, orang-orang Islam mengkhawatirkan sanak saudara mereka yang ikut pergi bersama orang-orang Yahudi tersebut. "Wahai Rasulullah, bukankah anak-anak kami dan saudara-saudara kami masih hidup bersama orang Yahudi Bani Nadhîr?", kata mereka. Maka turunlah ayat lâ ikerâh fì al-dîn. Rasulullah berkata, "saudara dan sahabat kalian telah diberi pilihan; bersama kalian (Islam) atau bersama mereka (Yahudi)". ${ }^{10}$

Kedua, al-Suddî berkata bahwa ayat lâ ikerâh fì al-dîn turun dalam kasus seorang laki-laki bernama Abû Ḥusayn yang memiliki dua orang anak. Alkisah, beberapa padagang Syam (sekarang Suriah) datang ke Madinah dengan membawa minyak. Ketika hendak keluar Madinah, mereka didatangi dua anak Abû Husayn tersebut. Lalu para pedagang itu mengajak dua anak tersebut masuk Kristen. Terpengaruh dengan ajakan tersebut, dua anak tersebut masuk Kristen. Dua-duanya pun dibawa ke Syam. Atas peristiwa tersebut, Abû Husayn mengadu ke Rasulullah dan berharap dua-duanya bisa dikembalikan ke Madinah. Dengan kasus ini, maka turunlah ayat lâ ikerâh fî al-dîn. ${ }^{11}$ Ibn Jarîr alTabarî mengutip cerita berbeda dari Saî̀d b. Jâbir, dari Ibn 'Abbâs bahwa terdapat seorang laki-laki dari Bani Sâlim b. 'Awf bernama Abû Husayn. Ia beragama Islam, sementara dua anaknya beragama Kristen. Lalu Abû Husayn bertanya pada Nabi, "bolehkan saya

masyarakat Arab secara umum. Itu sebabnya, banyak ayat al-Qur'ân yang hadir sebagai cerminan dari keadaan sosial-ekonomi-politik yang berkembang saat itu.

${ }^{9}$ al-Qurtubî, al-Jâmi“, Vol. 2, 239-240.

${ }^{10}$ Ibn Jarîr al-Ṭabarî, Jâmi al-Bayân fî Ta'wîl al-Qur'ân, Vol. 3 (Beirut: Dâr al-Kutub al-'Ilmîyah, 1999), 15. Bandingkan dengan Muhammad Rashîd Riḍ̂, Tafsîr al-Qur'ân al-Hakîm, Vol. 3 (Beirut: Dâr al-Kutub al-'Ilmîyah, 1999), 30-31; al-Alûsî, Rûh alMa'ânî, Vol. 2, 19-20; dan al-Khâzin, Lubab al-Ta'wîl, 171.

11 Abû al-Qâsim Mạ̣mûd b. 'Umar b. Aḥmad al-Zamakhsharî Jâr Allâh, al-Kashshâf 'an Haqẩiq al-Tanzîl wa 'Uyûn al-Aqâwil fî Wujûh al-Ta'wîl, Vol. 1 (Mesir: Dâr Miṣr, t.th.), 272. 
memaksa keduanya (masuk Islam), sementara mereka berdua tidak memeluk suatu agama selain Kristen?”. Maka turunlah ayat Lâ ikrâh fî̀ al-din. ${ }^{12}$

Ketiga, pendapat lain mengatakan bahwa ayat tersebut turun untuk menegaskan bahwa orang-orang Ahli Kitab yang sudah dewasa tidak bisa dipaksa masuk Islam (lam yujbar idhâ kânû kibâran). Sedangkan orang-orang Ahli Kitab yang sudah ditahan, baik kecil maupun dewasa, maka boleh bagi mereka dipaksa masuk Islam (fa innabum yujbarûn 'alâ dîn al-Islâm). Namun, tentang pendapat terakhir ini, alQurțuîi tidak menjelaskan nama-nama ulama yang berpendapat demikian. Sementara itu, Ibn Jarîr al-Ṭabarî mengutip pendapat Qatâdah bahwa orang Yahudi, Kristen, dan Majusi tidak bisa dipaksa masuk Islam sekiranya mereka membayar pajak pada negara Islam. ${ }^{13}$

Terkait dengan sebab turun ayat ini, al-Ṭabarî berkata, terdapat kecenderungan di Madinah saat itu di mana para orang tua diperbolehkan memaksa anak-anak mereka untuk mengikuti agama orang tua. Jika orang tua beragama Yahudi, maka anak di-Yahudi-kan. Begitu juga, sekiranya orang tua beragama Kristen, maka anak diKristen-kan. Tradisi ini berjalan hingga Islam datang; mereka juga memaksa anak-anak mereka memeluk Islam. Maka, turunlah ayat lâ ikrâh fì al-dîn yang menentang praktik pemaksaan tersebut. Melalui ayat ini, anak-anak diberi pilihan bebas untuk masuk ke dalam Islam tanpa paksaan (falamma jâ'a al-Islâm arâdu ikrâhabum 'alayh, fa nabâhum Allâh 'an dhâlik ḅattâ yakûn bum yakbtârûn al-dukhûl fî al-Islâm). ${ }^{14}$

Dari beragam versi sabab al-nuথûl tersebut, ada benang merah yang mempertautkan bahwa berdasarkan ayat tersebut segala bentuk pemaksaan untuk masuk suatu agama tidak bisa dibenarkan, baik dari Islam ke Yahudi-Nashrani maupun dari Yahudi-Nashrani ke dalam Islam. Begitu tegasnya larangan pemaksaan agama itu hingga seorang ibu yang melahirkan pun tidak diperbolehkan memaksa anaknya untuk memeluk agama seperti agama orang tuanya. Konsisten dengan sabab al-nu₹ûl itu, pemaksaan dalam konteks yang bagaimanapun tidak bisa dibenarkan.

12 al-Ṭabarî, Jâmi al-Bayân, 16; al-Bayḍ̂âî, Anwâr al-Tanæîl, Vol. 1, 557; dan Muhammad 'Abd al-Mun'im al-Jamâl, al-Tafsîr al-Farîd li al-Qur'ân al-Majîd (Kairo: Majma‘ al-Buhûth al-Islâmîyah, 1970), 256-257.

${ }^{13}$ al-Ṭabarî, Jâmi al-Bayan, Vol. 3, 18.

${ }^{14}$ Ibid., 15. 
Dengan mengetahui sabab al-nu₹ûl tersebut, jelas bahwa pemaksaan dalam agama tidak dapat dibenarkan. Ibrâhîm al-Hafnawî menegaskan bahwa kebebasan beragama merupakan prinsip dasar ajaran Islam, sehingga tidak ditemukan satu ayat pun dalam al-Qur'ân atau sebuah hadith yang bertentangan dengan prinsip dasar ajaran ini. ${ }^{15}$ Pendapat senada dikemukakan Muhammad Râshid Rị̂â dalam Tafsir al-Qur'ân al-Hakim. Karena keimanan merupakan pondasi agama yang esensinya adalah ketundukan diri, maka-menurut Riḍ̂a-ia tidak bisa dijalankan dengan pemaksaan. Dengan ini bisa dikatakan, beriman bukan merupakan keharusan atau kewajiban sehingga perlu dipaksakan dari luar. ${ }^{16}$ Beriman merupakan pilihan, kesadaran dan ketundukan subjektif manusia atas ajaran-ajaran Allah. Jika demikian sabab al-nuzûl ayat tersebut, maka pertanyaan berikutnya; bagaimana ulama menafsirkan ayat tersebut?

\section{Tafsir Ulama Konservatif terhadap Ayat Lâ Ikrâh fí al-Dîn}

Dari sudut gramatika bahasa Arab tampak bahwa kata "la" dalam ayat di atas termasuk "la linafy al-jins", yang berarti menafikan seluruh jenis paksaan dalam soal agama. Ayat ini juga dikemukakan dengan

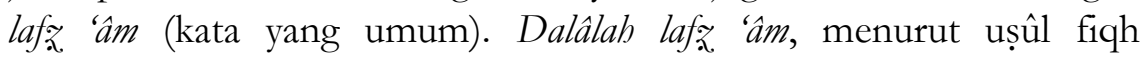
Hanafiyah, adalah qat î̀ (jelas-tegas) sehingga tidak mungkin di-takhsîș (dibatasi pengertiannya), apalagi di-naskh (dibatalkan) dengan dalil yang zannî (tidak jelas maknanya). ${ }^{17}$ Sementara al-Ṭabâtabââ̂ dalam alMìzân fì Tafsîr al-Qur'ân berpendapat, ayat itu tidak mungkin di-naskh tanpa me-naskh alasan hukumnya ('illat al-hukm). 'Illat hukum itu tertera secara eksplisit dalam kalimat berikutnya yang menyatakan, antara al-rushd (kebenaran) dan al-ghayy (kesesatan) sudah jelas.

Pertanyaannya, apa yang dimaksud dengan al-rushd dan al-ghayy tersebut? Sebelum menjawab pertanyaan itu, al-Bayḍ̂âî (w. 791) dalam Anwâr al-Tanzîl wa Asrâr al-Ta'wâl memulai pembahasannya dengan mendefinisikan apa itu pemaksaan (al-ikrâh)? Al-Bayḍ̂âi berpendapat bahwa pemaksaan itu adalah menyuruh orang lain untuk melakukan suatu tindakan seperti yang kita kehendaki. Selanjutnya alBayḍâwî berkata, al-rushd adalah keimanan, sedangkan al-ghayy itu adalah kekufuran. Menurutnya, sudah sudah jelas perbedaan antara

\footnotetext{
15 al-Qurțbî, al-Jâmi' li Aḅkam, Vol. 2, 240.

16 Ridha, Tafsîr al-Qur'ân, Vol. 3, 31; dan Abd Moqsith Ghazali, Argumen Pluralisme Agama (Depok: KataKita, 2009), 222.

${ }^{17}$ Ibid., 218.
} 
iman dan kafir. Jika keimanan itu adalah rushd yang membawa seseorang pada kebahagiaan abadi (al-sa'âdah al-abadîyah), sedangkan kekufuran adalah ghayy yang mengantarkan seseorang pada kecelakaan abadi. Baginya, orang berakal yang telah mengetahui perbedaan itu akan mendekat pada keimanan demi tercapainya kebahagiaankeselamatan sehingga tidak perlu pemaksaan (lam yahtâj ilâ al-ikrâh wa al-ijjâ).

Dengan demikian, menurut al-Bayḍ̂ûî, ayat lâ ikeâh fî al-dìn ini adalah kalimat berita yang harus dimaknai sebagai kalimat tuntutan, ${ }^{18}$ yaitu tuntutan meninggalkan pemaksaan dalam urusan agama. Jika dieksplisitkan, menurut al-Bayḍâwî, ayat tersebut akan berbunyi demikian, la takrahî fì al-dîn (jangan lakukan pemaksaan dalam soal agama). Alkazruni berasumsi bahwa larangan pemaksaan itu berarti, tidak pantas seseorang untuk dipaksa masuk ke dalam suatu agama (Islam), karena demikian jelasnya dalil-dalil qat î̀ tentang itu. Ayat yang melarang pemaksaan dalam soal agama ini, menurutnya, paralel dengan larangan memaksa anak gadis sebagai pelacur-sebagaimana ditegaskan dalam ayat al-Qur'ân (QS. al-Nûr [24]: 32), wa lâ takrahûu fatayâtikum 'alâ al-bighâ' in aradna taḥașsunan li tabtaghûu 'arad al-ḥayât aldunyâ (dan janganlah kalian paksa hamba sahaya perempuan kalian untuk melakukan pelacuran sedang mereka menginginkan kesucian karena kalian sedang hendak mencari keuntungan kehidupan dunia). ${ }^{19}$

Lebih lanjut, al-Alûsî mengutip pendapat para mufassir tentang tâghût. Ada yang berkata bahwa tâghût adalah setan. Pendapat ini dikemukakan 'Umar b. Khaț̣̂ab, al-Ḥasan b. 'Alî. Sedangkan Mujâhid, Qatâdah, Saî̀d b. Jubayr dan Ikrimah mengartikan tâghât dengan kâhin (dukun). Abû al-'Alîyah mengartikannya dengan penyihir. Mâlik b. Anas, memaknainya pada semua hal yang disembah selain Allah (kull mâ 'ubid min dûn Allâh). ${ }^{20} \mathrm{Ibn}$ 'Âshûr mengartikan țâghût dengan patung (al-awthân wa al-ạnâm). ${ }^{21}$ Al-Ṭabâțabấî menyebutkan bahwa tâghht itu

\footnotetext{
${ }^{18}$ Dalam uṣ̂l al-fiqh dikenal dua jenis tuntutan, yaitu tuntutan unttuk mengerjakan (talab al-fi'), dan tuntutan untuk meninggalkan (talab al-tark). Sekiranya tuntutan mengerjakan yang bersifat tegas disebut wajib, maka tuntutan mengerjakan yang tidak tegas disebut mandûb (sunnah). Begitu juga, jika tuntutan meninggalkan yang bersifat tegas disebut haram, maka tuntutan mengerjakan yang bersifat tidak tegas disebut makruh.

${ }^{19}$ al-Baydâwîi, Anwâr al-Tanzîl, Vol. 1, 557.

20 al-Alûsî, Rûh al-Ma'anî, Vol. 2, 20.

21 'Âshûr, al-Tahrîr, Vol. 3, dan Vol. 5, 28.
} 
bisa berupa patung, setan, jin, para pemimpin yang sesat, atau orangorang yang diikuti padahal Allah tidak rela orang itu diikuti. ${ }^{22}$ Sementara al-urwah al-wuthqâ diartikan al-Khâzin (w. 725 H.) sebagai dìn al-Islâm (agama Islam) yang kukuh yang dibawa Nabi Muhammad. Al-Khâzin berkata bahwa al-mutamassik bî al-dîn al-sahîh al-ladhî huwa dîn al-Islâm ke al-mutamassik bi al-shay' al-wâthiq al-ladhî lâ yumkin kasruh wa la inqitâ'ub (orang yang memeluk agama yang benar yang notabene adalah agama Islam seperti memegang sesuatu yang kokoh yang tidak mungkin goyah dan terputus). ${ }^{23}$

Fakhr al-Dîn al-Râzî berkata, dengan bukti dan dalil-dalil yang ada, begitu jelas perbedaan antara al-rushd dan al-ghayy, sehingga ayat itu akan berjalan sesuai dengan pengertian lahirnya, yaitu tidak adanya paksaan dalam soal agama. (fa kâna al-murâd annahû ḥasalat al-baynûnah bayn al-rushd wa al-ghayy bi sabab quwwat al-dalầil wa ta'kîd al-barâhin, wa 'alâ bâdha kâna al-laf̧̃ majra 'alâ zâabir). ${ }^{24}$ Lalu al-Râzî mengutip pendapat Abû Muslim dan al-Qaffâl yang berpendapat, ayat ini hendak menegaskan bahwa keberimanan harus didasarkan pada suatu pilihan sadar (al-tamkîn wa al-ikhtiyâr) dan bukan pada suatu tekanan (al-ijbâr wa al-qașr). ${ }^{25}$ Menurut Muhammad Nawawi al-Jawi dalam bukunya, Marah Labidr, ayat ini berarti bahwa pemaksaan untuk masuk dalam suatu agama tidak dibenarkan. ${ }^{26}$

Menurut al-Zamakhsharî, melalui ayat tersebut Allah hendak menegaskan bahwa soal keimanan tidak bisa dijalankan dengan paksaan, tapi dengan pilihan sadar yang bersangkutan. Ayat ini, menurut al-Zamakhsharî, satu pengertian dengan ayat lain yang menunjukkan ketidakmauan Allah untuk mengimankan seluruh manusia. Ayat itu tertuang dalam QS. Yunus [10]: 99 yang berbunyi, "wa law shâ'a rabbuk la'âman man fî al-arḍ kulluhum jamı̂‘̂a, afa anta tukrih al-nâs hattâ yakûn mu'minîn" (Jikalau Tuhanmu menghendaki, tentu akan beriman semua orang yang ada di bumi seluruhnya. Maka apakah kamu hendak memaksa manusia supaya mereka menjadi

22 Muḥammad Husayn al-Ṭabâtabâî̀, al-Mîzân fî Tafsîr al-Qur'ân, Vol. 2 (Beirut: Mu'assasat al-'Âlamî li al-Maṭû́ât, 1991), 348. Bandingkan dengan al-Khâzin, Lubab al-Ta'mîl, 171.

23 al-Khâzin, Lubab al-Ta'mîl, 171.

${ }^{24}$ Fakhr al-Dîn al-Râzî, Mafâtị̧ al-Ghayb, Vol. 4, dan Vol. 7 (Beirut: Dâr al-Fikr, 1995), 17.

25 Ibid., 16. Bandingkan dengan Ghazali, Argumen Pluralisme, 217.

${ }^{26}$ Muhammad Nawawi al-Jawi, Marah Labidə, Vol. 1 (Indonesia: Dâr Ihyầ' al-Kutub al-'Arabîyah, t.th.), 74. Bandingkan dengan Ghazali, Argumen Pluralisme, 217. 
orang-orang beriman semuanya. Tidak seorang pun akan beriman kecuali dengan izin Allah). ${ }^{27}$

Sementara itu, Ibn Kathîr mengutip pandangan ulama yang menyatakan bahwa ayat tersebut sudah di-naskh ayat perang (ayat alqitâl. Menurutnya, seluruh manusia wajib diseru masuk agama Islam. Sekiranya mereka tidak mau masuk Islam dan tidak mau membayar retribusi (jizyah), mereka wajib diperangi. Lalu Ibn Kathîr mengutip pandangan para ulama mengenai "al-"urwah al-wuthqâ". Bagi Mujahid, al-"urwah al-wuthqâ itu adalah iman. Sedangkan bagi al-Suddî, al-urwah al-wuthqâ (tali yang kuat) itu adalah Islam. Jika menurut Sa î̀d b. Jubayr dan al-Ḍaḥhâk, al-umvah al-wuthqâ adalah kalimat lâ ilâh illâa Allâh, maka menurut Anas b. Mâlik, al-'urwah al-wuthqâ adalah alQur'ân itu sendiri. Bahkan, Sâlim b. Abî al-Ja'ad mengartikannya dengan cinta dan benci di jalan Allah (al-hubb fì Allâh, al-bughd fí Allâh). Terhadap tafsir-tafsir itu, Ibn Kathîr membenarkan semuanya. ${ }^{28}$ Penjelasan ini menunjukkan pandangan ekslusif Ibn Kathîr.

Berbeda dengan Ibn Kathîr, Muhammad Râshid Riḍ̂a menegaskan, ayat tersebut bisa dipakai untuk menolak orang yang berkata bahwa Islam pro-kekerasan, tegak dengan pedang dan peperangan. Tidak sedikit orang, demikian Rị̣â, yang berkata barangsiapa menerima Islam akan selamat, dan barangsiapa menolaknya, maka pedang akan berjalan padanya. Jika pandangan itu benar, maka-menurut Riḍ̂a-mengapa dalam periode Makkah, pedang tidak dijadikan sebagai alat pemaksa; mengapa tidak ada perintah perlawanan ketika umat Islam difitnah dan disiksa selama periode Makkah; mengapa Nabi dan umat Islam disuruh berhijrah ketimbang melawan orang musyrik Makkah? Apakah mereka akan berkata, demikian Rị̂â, bahwa pemaksaan agama baru berjalan di Madinah ketika Islam sudah mereguk kekuasaan? Mengapa dalam periode Madinah orang tua dilarang memaksa anaknya untuk masuk ke dalam Islam. ${ }^{29}$ Pertanyaan-pertanyaan ini diajukan Riḍ̂a untuk menyangkal kecenderungan menjadikan al-Qur'ân sebagai poros kekerasan dan pemaksaan.

Al-Ṭabâtabâ'î berargumen bahwa soal agama adalah soal keyakinan yang bersemayam dalam hati seseorang. Dengan demikian, keimanan tidak bisa hidup dalam hati yang dipaksakan. Ia pun

27 al-Zamakhsharî, al-Kashshâf, 271.

${ }^{28}$ Ibn Kathîr, Tafsîr al-Qur'ân al-Az̧îm, Vol. 1 (Beirut: Dâr al-Fikr, 1999), 354-355.

${ }^{29}$ Riḍ̂, Tafsîr al-Qur'ân, Vol. 3, 31. 
menegaskan bahwa ayat ini merupaksan (salah satu) bukti bahwa Islam tidak dibangun dengan pedang dan darah; Islam tidak dideklarasikan dengan paksaan. Dengan ayat ini, ia menolak anggapan sebagian orang bahwa Islam adalah agama pedang (inna al-Islâm dîn alsayf) dengan bertumpu pada ayat jihad. Ayat perang, demikian alTabâtabâ‘̂̂, bukan untuk menyebarkan Islam dengan kekuatan dan pemaksaan (bast al-dîn bi al-quwwah wa al-ikrâh), melainkan untuk menegakkan kebenaran dan membela ajaran tauhid.

Lebih lanjut al-Ṭabâtabâî̀ menegaskan bahwa ayat lâ ikrâh fì al-dìn tidak bisa dibatalkan ayat perang. Teks ayat qad tabayyan al-rushd min alghayy (bahwa sungguh sudah jelas antara petunjuk dan kesesatan) adalah alasan hukum yang berlaku abadi, sehingga tidak mungkin dibatalkan ayat pedang. Ia berkata, "inna al-nâsikh mâ lam yansakh 'illat al-hukm lam yansakh nafs al-hukm” (ayat pembatal sekiranya tidak bisa membatalkan illat hukum suatu ayat, maka ia tidak bisa membatalkan hukum dalam ayat itu). Di ujungnya, al-Ṭabâtabấî menyimpulkan, ayat lâ ikerâh fî al-dîn harus tetap berlaku dalam kondisi apapun dan tidak boleh dihapuskan. ${ }^{30}$

Jamâl al-Dîn al-Qâsimî dalam Maḥâsin al-Ta'wîl mengatakan, ayat ini hendak menegaskan bahwa seseorang tidak boleh dipaksa masuk Islam, karena kebenaran Islam sudah cukup jelas baik dalil-normatif

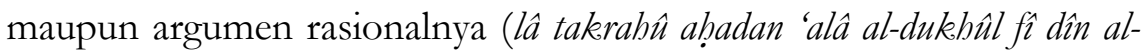
Islâm fa innab̂̀ bayyin wâdị̣ jalîy dalâiluh wa barâhinub). Dengan demikian, ayat-ayat jihad tidak bisa dipakai untuk memaksa seseorang masuk Islam. ${ }^{31}$ Dari sini diketahui, al-Qâsimî tidak termasuk ulama yang berkata bahwa ayat lâ ikrâh fí al-dîn telah dihapus ayat perang.

Menurut Ibn 'Âshûr, ayat lâ ikerâh fî̀ al-dîn ini turun setelah terjadinya penaklukan kota Makkah, setelah orang-orang Arab berduyun-duyun masuk Islam dan setelah Ka'bah bersih dari simbolsimbol kemusyrikan. Setelah itu semua terjadi, Allah membatalkan peperangan atas dasar agama. Dengan perkataan lain, ayat lâ ikrâh fî aldîn telah membatalkan ayat-ayat perang dalam al-Qur'ân. Dengan demikian, masuknya seseorang ke dalam Islam harus didasarkan pada pilihan bebas tanpa paksaan (dûn jabr wa lâ ikrâh). ${ }^{32}$ Lebih lanjut, Muhammad 'Abd al-Mun'im al-Jamâl berkata bahwa lâ ikerâh fì al-dîn

\footnotetext{
30 al-Ṭabâtabâ'î, al-Mî̃ân, Vol. 2, 347-348.

31 Jamâl al-Dîn al-Qâsimî, Mạ̣âsin al-Ta'mûl, Vol. 2 (Kairo: Dar al-Hadîth, 2003), 235-236.

32 ‘Âshûr, al-Taḅrî, Vol. 3, Vol. 5, 25-26.
} 
artinya lâ ikrâh fî̀ dukhûl al-Islâm wa lâ yuqhar al-nâs 'alâ i'tinâqih (tidak ada paksaan untuk masuk Islam dan manusia tidak boleh dipaksa untuk memeluk Islam)..$^{33}$

Al-Sha' rawî mengartikan ayat lâ ikrâh fì al-dîn ini dengan anna Allâh lam yakrah khalqah wa huwa khâliquhum 'alâ dîn (Allah tidak memaksa makhluk yang diciptakan-Nya untuk memeluk suatu agama). Menurut al-Sha'rawî, alasan tidak adanya paksaan dalam Islam itu karena sudah cukup jelas perbedaan antara jalan keselamatan (taríq al-najâh, al-rushd) dan jalan kebinasaan (tarîq al-balâk, al-ghayy). Menurut al-Sha'rawî, seorang rasul diutus untuk menyampaikan ajaran bukan untuk memaksakan ajaran. Namun, kata al-Sha' rawî sekiranya seseorang telah menetapkan diri untuk masuk Islam, maka yang bersangkutan terikat untuk mengamalkan ajaran Islam. Tidak bisa orang Islam dengan alasan lâ ikerâh fî̀ al-dîn tidak mengerjakan salat. Begitu seseorang menetapkan masuk Islam, demikian al-Sha'rawî, maka ia terikat untuk mengamalkan ajaran Islam. ${ }^{34}$

Mengikuti al-Sha'rawî, M. Quraish Shihab berkata, jika seseorang telah memilih satu aqidah, aqidah Islam misalnya, maka dia terikat dengan segala tuntunan-Nya dan berkewajiban melaksanakan perintah-perintah-Nya. Dia terancam sanksi bila melanggarnya. Shihab menegaskan, seseorang tidak boleh berkata, "Allah telah memberi saya kebebasan untuk salat atau tidak, berzina atau nikah". Sebab, demikian Shihab, bila seseorang telah menerima aqidah Islam, maka dia harus melaksanakan tuntunannya. ${ }^{35}$ Dengan ini, Shihab mungkin hendak menegaskan bahwa kebebasan yang dimaksudkan dalam ayat lâ ikrâh fî̀ al-dîn itu tidak mencakup kebebasan untuk melaksanakan dan tidak melaksanakan ajaran Islam bagi orang Islam. Dengan perkataan lain, begitu seseorang menetapkan dan memilih Islam sebagai agamanya, maka ia terikat dengan seluruh ketentuan dan ajaran Islam yang dibawa Nabi Muhammad.

Lebih dari al-Sha'rawî dan Shihab, Sayyid Quṭb menegaskan bahwa ayat lâ ikerâh fì al-dîn adalah ayat yang mendukung tegaknya salah satu hak asasi manusia, yaitu hak bebas memilih suatu agama. Quṭb berkata, inna ḥurrîyat al-itiqâad biya awwal ḥuqûq al-insân al-latî

\footnotetext{
33 al-Jamâl, al-Tafsîr al-Farîd, 256.

34 Muhammad Mutawallî al-Sha'rawî, Tafsîr al-Sha'rawî, Vol. 2 (Mesir: Majma' alBuhûth al-Islâmîyah, 1991), 1126-1128.

${ }_{35}$ M. Quraish Shihab, Tafsir al-Misbah: Pesan, Kesan, dan Keserasian al-Qur'an (Jakarta: Lentera Hati, 2009), 668.
} 
yathbut lah biha wasf insân (kebebasan berkeyakinan adalah bagian hak asasi manusia yang melekat pada setiap orang sejak awal). Menurut Quṭb, ayat lâ ikrâh fì al-dîn ini menampik seluruh jenis pemaksaan (nafy jins al-ikrâh). Terlebih, urusan keyakinan adalah urusan penerimaan setelah mendapatkan penjelasan, bukan urusan intimidasi dan pemaksaan (qadîyah iqtinâ' ba'd al-bayân wa al-idrâk wa laysat qadîyah ikrâh wa ghadab wa ijbâr). ${ }^{36}$

Wahbah al-Zuhaylî menegaskan, dalam sejarah Islam tidak ada sejarah pemaksaan. Tercatat dalam sejarah, demikian al-Zuhaylî, orang-orang masuk Islam karena pilihan sadar bukan pemaksaan. Ia berkata, "inna al-ikrâh fî al-dîn mamnû"" (sesungguhnya pemaksaan dalam soal agama adalah terlarang). ${ }^{37}$ Dengan ini, al-Zuhaylî hendak menegaskan bahwa pilihan seseorang untuk memeluk Islam harus berdasarkan pilihan sadar dan bukan karena paksaan dari luar.

Tidak hanya al-Zuhaylî yang berpendapat demikian, Hasbi ashShiddieqy juga. Dengan merujuk pada sejumlah kitab tafsir, ashShiddieqy berkata bahwa tidak boleh ada paksaan dan tindakan kekerasan untuk masuk ke dalam agama. Iman itu tunduk dan khudû (patuh). Untuk mencapai hal itu, demikian ash-Shiddieqy, tidak bisa dilakukan dengan paksaan dan tekanan, tetapi harus dengan alasan dan penjelasan yang bisa meyakinkan. Sebab, menurut ash-Shiddieqy, telah jelas bahwa agama Islam membawa petunjuk dan kemenangan, sedangkan agama lain sesat dan menyimpang dari kebenaran. ${ }^{38}$

Berbagai tafsir ayat lâ ikeâh fî al-dîn yang diajukan para mufassir di atas berujung pada kesimpulan bahwa menurut mereka tidak boleh ada paksaan bagi seseorang untuk masuk Islam. Sebab, keimanan dan keislaman yang dibangun di atas fondasi pemaksaan tidak akan berdiri kokoh sehingga mudah rapuh dan hancur. Itu sebabnya, berdasarkan sabab al-nuzûl ayat tersebut, orang tua pun tidak dibolehkan melakukan pemaksaan agar agama anak mengikuti agama orang tuanya. Tidak hanya orang tua, seorang kepala negara seperti Khalifah 'Umar b. alKhattâb pun tidak diberi kewenangan untuk memaksa seseorang memeluk Islam. Sebagaimana Nabi Muhammad, para ulama hanya diberi kewenangan untuk menyampaikan kebenaran ajaran Islam bukan untuk memaksa orang lain untuk masuk Islam. Allah swt

\footnotetext{
36 Sayyid Qutb, Fî Zilâl al-Qur'ân, Vol. 1 (Kairo: Dâr al-Shurûq, 2007), 291.

37 Wahbah al-Zuhaylî, al-Tafsîr al-Wasît, Vol. 1 (Beirut: Dâr al-Fikr, 2000), 148.

38 Teungku Muhammad Hasbi ash-Shiddieqy, Tafsir al-Qur'an al-Majid An-Nuur, Vol. 1 (Semarang: Pustaka Rizki Putra, 2000), 450.
} 
berfirman (QS. al-Ghâshiyah [88]: 21-22), “fa dhakkir innamâ anta mudhakkir, lasta 'alayhim bi muṣaytire" (Maka berilah peringatan, karena sesungguhnya engkau (Muhammad) hanya pemberi peringatan. Engkau (Muhammad) bukanlah orang yang berkuasa atas mereka). Bahkan, di ayat lain Allah menegaskan, "Dan katakanlah Muhammad, "kebenaran itu datangnya dari Tuhanmu". Barangsiapa menghendaki (beriman), maka berimanlah. Barangsiapa menghendaki kafir, maka kafirlah" (QS. al-Kahf [18]: 29).

\section{Pandangan Ulama Progresif tentang Ayat Lâ Ikrâh fi al-Dîn}

Penting dikemukakan bahwa dalam perkembangan dan dinamika masyarakat tidak sedikit orang yang memeluk Islam bukan karena pilihan sadar yang bersangkutan dan bukan juga karena paksaan dari luar melainkan karena bentukan lingkungan di mana ia tinggal dan dibesarkan. Dalam masyarakat tradisional, kepenganutan seseorang atas suatu agama atau keyakinan biasanya akan sangat dipengaruhi oleh agama yang dianut orang tua yang bersangkutan. Jika orang tua beragama Islam biasanya mereka akan mendidik sang anak dengan tata cara dan ritual Islam, sehingga agama Islam akan terinternalisir dan terserap oleh sang anak tanpa proses pemaksaan. Di sini sang anak mula-mula menerima suatu agama secara taken for granted melalui proses-proses alamiah-kultural bukan proses akademik-intelektual. ${ }^{39}$

Menganut agama yang "diwariskan" orang tua ini biasanya menimbulkan dua reaksi dari sang anak ketika ia sudah dewasa. Pertama, tidak cukup menerima penjelasan dari orang tua tentang agama itu, sang anak bisa juga hendak memperluas wawasan keagamaannya dengan membaca buku-buku paling otoritatif tentang tafsir atas agama itu. Bisa juga ia mendengar penjelasan dari para intelektual yang dikenal memiliki pengetahuan yang luas tentang seluk-beluk agama itu. Dari penjelajahan intelektual itu, ia yang pada mulanya menerima agama itu secara kultural kini bergerak menjadi penerimaan intelektual. Ia misalnya tidak mempersoalkan agama Islam yang dipilihkan orang tuanya. Ia tidak merasa perlu untuk konversi agama, tetapi yang relevan baginya sekarang adalah bagaimana

\footnotetext{
${ }^{39}$ Menarik membaca proses keberislaman Ulil Abshar Abdalla, pemikir liberal Islam Indonesia. Dalam buku Menyegarkan Kembali Pemikiran Islam, Ulil menuturkan proses penerimaannya terhadap Islam yang semula bersifat kultural kemudian berubah seiring waktu dengan penerimaan intelektual. Lihat Ulil Abshar Abdalla, Menyegarkan Kembali Pemikiran Islam: Bunga Rampai Surat-surat Tersiar (Jakarta: Nalar, 2007), 163166.
} 
memahami Islam sesuai dengan kebutuhan spiritualitas dirinya sekarang. Dalam reaksi pertama ini, tidak ada problem teologis yang perlu ditanggulangi, karena sang anak tetap dengan agama lamanya. Kedua, ketika menginjak dewasa tidak sedikit anak merasa tidak cocok dengan "agama warisan" orang tuanya, sehingga yang bersangkutan menginginkan untuk pindah ke agama lain, tidak terkecuali pindah misalnya dari agama Islam ke agama Kristen. Dengan perkataan lain, agama yang "dipilihkan" orang tua ketika periode anak-anak dirasa tidak relevan dan belum sanggup memberikan efek kebahagiaan ketika fase dewasa. Karena itu, ia memutuskan untuk hijrah ke agama lain atau bahkan tidak beragama sama sekali. Fenomena ini banyak terjadi terutama di lingkungan masyarakat kota, di mana orang tua memberikan kebebasan penuh kepada anak, termasuk kebebasan untuk memilih atau keluar dari suatu agama.

Dalam konteks itu, pertanyaan yang muncul adalah jika al-Qur'ân membebaskan seseorang untuk masuk Islam, maka apakah juga alQur'ân membebaskan seseorang untuk keluar dari Islam. Jika memperhatikan penjelasan-penjelasan para mufassir di atas, tidak satu pun dari mereka yang menarik pengertian ayat ini pada kebebasan seseorang untuk keluar dari Islam. Mereka sepakat tentang kebebasan seseorang untuk masuk Islam, tapi tidak untuk keluar dari Islam. Pandangan ini bisa dipahami, karena dalam kasus keluar dari Islam, ulama tidak bertumpu pada ayat tersebut, melainkan pada hadîth yang berbunyi, "man baddal dînah fa uqtulûh" (barangsiapa yang pindah agama, maka bunuhlah). Akram Rị̣â dalam al-Riddah wa al-Hurrîyah alDinŷah mengatakan bahwa hạâth ini tercantum di sejumlah bukubuku hạâith, seperti Sahîh al-Bukbârî, Sunan al-Turmudhî, Sunan alNasầ, Sunan Abî Dâwud, Sunan Ibn Mâjah, Musnad al-Imâm Aḥmad, dan Munatța' al-Imam Mâlik ${ }^{40}$. Ini menunjukkan bahwa hadîth itu ada dan tidak terbantah. Hadîth ini rupanya menjadi "sandungan" utama para penggerak ide kebebasan beragama.

Lalu, bagaimana meletakkan hadîth "man baddal dînah fa uqtulûh" dalam bingkai ayat "lâ ikrâh fî al-dîn". Dalam elaborasi Jawdat Saîd, ia membahas soal pengertian al-rushd dan al-ghayy. Menurut Saî̀, yang dimaksud dengan pemaksaan (al-ikrâh) adalah alghayy dan ini adalah jalan salah (al-tarîq al-kbâti ). Sedangkan yang dimaksud dengan tanpa paksaan (al-lâ ikrâh) adalah al-rushd dan ini

\footnotetext{
40 Akram Riḍâ, al-Riddah wa al-Hurrîyah al-Dîniyah (t.t.: Dâr al-Wafâ, 2006), 1-41.
} 
adalah jalan benar (al-tarîq al-sahîh). Pengertian ayat itu adalah "tidak ada paksaan dalam agama. Sungguh sudah jelas (perbedaan) antara tanpa paksaan dan pemaksaan". Berbeda dengan kebanyakan para mufassir, Sa îd menafsir kata "tâghût" dalam lanjutan ayat itu sebagai orang yang memaksakan pemikiran dan keyakinannya kepada orang lain, dan membunuh orang yang berbeda keyakinan dengan dirinya. ${ }^{41}$

Perihal ayat tersebut, Saî̀d mengemukakan pandangannya. Pertama, ayat itu memberi jaminan kepada orang lain untuk tidak mendapatkan paksaan dari seseorang. Ayat itu memberi jaminan agar seseorang tidak dipaksa orang lain tentang sesuatu hal, termasuk urusan agama. Orang tua saja tidak diperkenankan memaksa sang anak untuk masuk pada agama orang tua, apalagi orang lain. Ayat ini merupakan teks fondasi atau dasar penyikapan Islam terhadap jaminan kebebasan beragama. Sa'îd menyebut lâ ikrâh fî̀ al-dîn sebagai ayat kabîrah jiddan (ayat universal). Apalagi, menurut Saî̀, ayat itu dinyatakan persis setelah ayat kursi yang dianggap sebagai salah satu ayat paling utama. Jika ayat kursi mengandung ajaran penyucian Allah, maka ayat tersebut mengandung penghormatan kepada manusia, yang salah satunya adalah menjamin hak kebebasan beragama. ${ }^{42}$ Kedua ayat itu bisa dipahami sebagai kalimat perintah (kalâm inshầ' $)$ dan sebagai kalimat informatif (kalâm ikhbârì). Sebagai kalimat perintah, ia menyuruh seseorang untuk tidak melakukan pemaksaan kepada orang lain. Sebagai kalâm ikhbârî, ayat itu memberitahukan bahwa seseorang yang dipaksa masuk pada suatu agama sementara hatinya menolak, maka orang itu tidak bisa dikatakan telah memeluk agama itu. Ini karena agama ada di dalam kemantapan hati, bukan dalam ungkapan lisan. Ketiga, ayat itu turun untuk melarang pemaksaan dalam soal agama. Satu tarikan nafas dengan itu, ayat ini dengan sendirinya melarang membunuh orang yang pindah agama (murtad). Inilah kutipan pendapat Sa'îd, "saya berpendapat bahwa ayat ini merupakan teks yang akurat yang mengharamkan pembunuhan orang murtad. Pendapat yang menyatakan bahwa orang murtad harus dibunuh memang cukup populer. Tapi, tidak berarti pendapat yang populer itu benar. Popularitas tidak menjadi rujukun hukum. Kekeliruan ini bermula dari hadîth man baddal dînah fa uqtulûh. Jika saya mengambil

\footnotetext{
${ }^{41}$ Jawdat Saî̀d, Lâ Ikrâh fì al-Dîn: Dirâsât wa Abhâth fî̀ al-Fiker al-Islâmî (Damaskus: Markaz al-'Ilm wa al-Salâm li al-Dirâsât wa al-Nashr, 1997), 25-26; dan Ghazali, Argumen Pluralisme, 218.

${ }^{42}$ Saî̀, Lâ Ikrâh, 13.
} 
satu pendapat bahwa hadith tidak bisa me-naskh al-Qur'ân, maka jelas dalam al-Qur'ân tidak ditemukan hukum bunuh bagi orang murtad. Dengan demikian, orang murtad tidak boleh dibunuh. Tambahan pula, hadîth itu tidak jelas sebab kehadiran (sabab al-murûd)-nya. Maka kelirulah, orang yang membunuh orang lain yang berkata bahwa orang murtad tidak dibunuh". ${ }^{43}$

Paralel dengan pendapat Sacîd adalah pendapat Jamâl al-Bannâ. Dalam buku Tafnîd Da'wâ Hadd al-Riddab ${ }^{44}$ yang khusus bicara soal hukum murtad, Jamâl al-Bannâ dengan merujuk pada sejumlah ayat dalam al-Qur'ân berkata bahwa [1]. Soal iman dan kufr merupakan soal pribadi (qadîyah shakbsîyah) yang tidak boleh diintervensi. Allah memberi kebebasan kepada manusia untuk memilih antara beriman dan kafir. Ayat lâ ikerâh fî̀ al-dîn tidak di-mansûkh-kan oleh ayat perang. Ayat itu, demikian al-Bannâ, untuk menghapus semua praktik pemaksaan termasuk memaksa orang orang Yahudi dan Nashrani masuk Islam; [2]. Hidayah itu dari Allah, dan akan berjalan sesuai dengan kehendak Allah; [3]. Setiap nabi datang dengan membawa kabar gembira dan peringatan bukan kecaman dan pemaksaan; [4]. Perbedaan-perbedaan aqidah yang terjadi di kalangan manusia merupakan salah satu kehendak Allah; dan [5]. Tidak ada sanksi hukum duniawi bagi orang murtad.

Untuk mengukuhkan argumennya tersebut al-Bannâ menunjukkan sejumlah bukti. Alkisah, pada zaman Rasulullah ada 12 orang murtad (keluar dari Islam), di antaranya al-Hârith b. Suwayd alAnșârî. Mereka kemudian pindah dari Madinah ke Makkah. Rasulullah tidak menghukum bunuh mereka itu. Nabi hanya bersabda bahwa barangsiapa mencari agama selain Islam, maka ia tidak akan diterima dan di akhirat termasuk orang-orang yang merugi (wa man yabtagh $\hat{\imath}$ ghayr al-Islâm dînâ fa lan yuqbal minh wa buwa fî al-âkbirah min al-khâsirîn). Al-Bannâ juga menambahkan kisah 'Abd Allâh b. Jạ̣sh yang keluar dari Islam, lalu pindah ke Habasyah dan masuk Kristen. Terhadap kasus Ibn Jaḥsh ini, Rasulullah tidak menyuruh para sahabat untuk membunuhnya dan tidak juga meminta raja Najasyi untuk menyerahkan Ibn Jahsh ke pangkuan umat Islam untuk dieksekusi mati. Menurut al-Bannâ, ini menunjukkan bahwa Rasulullah tidak menetapkan sanksi hukum duniawi bagi orang murtad. Tidak ada

\footnotetext{
${ }^{43}$ Ibid., 26 dan 36-39; dan Ghazali, Argumen Pluralisme, 219.

${ }^{44}$ Jamâl al-Bannâ, Tafnîd Da'wâ Ḥadd al-Riddah (Kairo: Dâr al-Fikr al-Islâmî, 2006), 9 .
} 
orang murtad yang dibunuh pada zaman Nabi. Pembunuhan terhadap orang murtad baru terjadi setelah Rasulullah tidak ada, meninggal dunia.

Tidak hanya Jawdat Sa îd dan Jamâl al-Bannâ yang berpendapat demikian. Nurcholish Madjid (Cak Nur) juga mengajukan keberatan yang sama sekiranya hukum bunuh bagi orang murtad diterapkan. Bagi Cak Nur, hukum bunuh bagi murtad itu merupakan produk figh yang tidak absolut. Fiqh murtad itu, demikian Cak Nur, lahir dalam konteks ketika periode awal Islam mewajibkan seluruh umat Islam menjadi anggota militer. Saat itu, keluar dari Islam dianggap sebagai tindakan disersi yang bisa dihukum bunuh. Cak Nur menambahkan bahwa fiqh murtad itu muncul jauh sebelum dikenal konsep negara bangsa (nation state). Artinya, dalam konteks modern sekarang, fiqh murtad itu perlu diperbarui. Bagi Cak Nur, hadîth "man baddal dînah fa uqtulûh" bertentangan dengan visi dasar al-Qur'ân yang mendukung kebebasan beragama dan Hak Asasi Manusia. Tidak ada ayat tegas yang memberi license to kill terhadap orang murtad. ${ }^{45}$ Dengan tegas Cak Nur mengatakan:

Pernah saya lontarkan bahwa salah satu poin dalam deklarasi (HAM) itu adalah kebebasan beragama, termasuk kebebasan pindah agama. Itu merupakan anjuran dan toleransi untuk murtad. Pertama, itu normatif. Tapi, yang lebih penting, normatif fiqh yang historis, yaitu bahwa hukuman atas orang murtad itu dibunuh adalah hukum fiqh. Tidak ada di dalam al-Qur'ân. Yang ada di al-Qur'ân, hukumannya hanya dikutuk di akhirat saja. ${ }^{46}$

Berbekal ayat lâ ikrâh fî al-dîn, Cak Nur mengatakan bahwa tidak dibolehkannya memaksakan suatu agama kepada seseorang karena setiap manusia dianggap telah mampu dan harus diberi kebebasan untuk membedakan dan memilih sendiri mana yang benar dan mana yang salah. Manusia, demikian Cak Nur, dianggap telah dewasa sehingga dapat menentukan sendiri jalan hidupnya yang benar, dan tidak perlu lagi dipaksa-paksa seperti orang belum dewasa. ${ }^{47}$ Di sinilah Cak Nur hendak menempatkan manusia sebagai makhluk otonom yang bebas menentukan dan memilih agama yang diyakininya.

45 Mohammad Monib, dan Islah Bahrawi, Islam, dan Hak Asasi Manusia dalam Pandangan Nurcholish Madjid (Jakarta: Kompas-Gramedia, 2011), 192.

46 Ibid., 192. Bandingkan dengan Nurcholish Madjid, Demi Islam, Demi Indonesia (Jakarta: Paramadina, 1999), 273.

${ }^{47}$ Nurcholish Madjid, Pintu-pintu Menuju Tuhan (Jakarta: Paramadina, 1995), 218. 
Satu tarikan nafas dengan Cak Nur, Abdurrahman Wahid (Gus Dur) menyatakan kegetirannya sekiranya hukum bunuh diterapkan bagi orang Islam yang pindah agama. Gus Dur mengajukan pertanyaan, kalau fiqh murtad itu diberlakukan, maka lebih dari 20 juta jiwa manusia Indonesia yang berpindah agama dari Islam ke Kristen sejak tahun 1965 harus dihukum mati. Dapatkah hal itu dilakukan? Menurut Gus Dur, itulah pertanyaan yang tidak ada jawabnya. Sebab, demikian Gus Dur, jika itu terjadi, maka itulah kenyataan yang demikian besar mengguncang perasaan kita.

Memperhatikan cara Gus Dur mengajukan pertanyaan, maka ia seperti dilanda dilema. Di satu sisi, Gus Dur tidak bisa mengelak fakta tentang adanya hukum bunuh bagi orang murtad. Sementara, di sisi lain, ia juga tidak bisa menutupi penerimaannya terhadap Deklarasi Universal HAM PBB (Perserikatan Bangsa-Bangsa) yang memandang berpindah agama sebagai bagian Hak Asasi Manusia. Tidak lama dalam suasana dilematis, Gus Dur akhirnya menentukan sikap akademik bahwa hukum fiqh harus diselaraskan dengan dinamika zaman. Gus Dur berkata:

Dengan demikian menjadi jelas bahwa di hadapan kita hanya ada satu dari dua kemungkinan; menolak Deklarasi Universal HAM itu sebagai sesuatu yang asing bagi Islam, seperti yang dilakukan Abû al-A'lâ alMawdûdî terhadap Nasionalisme atau justru merubah diktum fiqh/hukum Islam itu sendiri. Sikap menolak, hanya akan berakibat seperti sikap burung onta yang menolak kenyataan dan menghindarinya dengan bersandar kepada lamunan indah tentang keselamatan diri sendiri. Sikap seperti ini hanya akan berarti menyakiti diri sendiri dalam jangka panjang. Dengan demikian, mau tidak mau kita harus menemukan mekanisme untuk merubah ketentuan fiqh/hukum Islam yang secara formal sudah berabad-abad diikuti. Tetapi, di sinilah terletak kebesaran Islam, yang secara sederhana menetapkan keimanan kita hanya kepada Allah dan utusan-Nya sebagai sesuatu yang tidak bisa ditawar lagi. Beserta beberapa hukum mublkamât lainnya, kita harus memiliki keyakinan akan kebenaran hal itu. ${ }^{48}$

Seperti terpampang dalam pernyataan di atas, Gus Dur memang tidak menjelaskan mekanisme teknis-akademis untuk mereformasi ketentuan fiqh tersebut. Gus Dur tidak menyebutkan apakah penolakannya terhadap hukum bunuh bagi orang murtad itu tegak di atas fondasi ayat lâ ikrâh fì al-dîn atau hadîth Nabi yang lain. Melalui

48 Abdurrahman Wahid, Islamku, Islam Anda, Islam Kita (Jakarta: The Wahid Institute, 2006), 122. 
penjelasannya di atas diketahui bahwa Gus Dur lebih memilih masuk pada argumen HAM ketimbang terlibat dalam debat penafsiran yang melelahkan. Dengan itu, Gus Dur menyetujui dilakukannya ratifikasi kovenan-kovenan internasional terkait Hak Asasi Manusia.

Sekiranya ditelusuri ke belakang melalui sejarah konstitusi di Indonesia, maka apa yang dikatakan Cak Nur dan Gus Dur itu tidak sepenuhnya baru. Indonesia pernah memiliki sebuah konstitusi yang menjamin kebebasan beragama secara penuh, yaitu UUD RIS 1950. Dalam konstitusi itu disebutkan bahwa kebebasan beragama dan berkeyakinan tidak hanya mencakup kebebasan untuk masuk pada suatu agama melainkan juga kebebasan untuk keluar dari suatu agama. ${ }^{49}$ Dalam pasal 18 UUD RIS itu disebutkan:

Setiap orang berhak atas kebebasan pikiran keinsyafan batin dan agama; hal ini meliputi pula kebebasan bertukar agama atau berkeyakinan, begitu pula kebebasan menganut agama dan keyakinannya, baik sendiri atau bersama-sama dengan orang lain, baik di muka umum maupun dalam lingkungannya sendiri dengan jalan mengajarkan, mengamalkan, beribadat, menaati perintah atau aturan-aturan agama, serta dengan jalan mendidik anak-anak dalam iman dan keyakinan orang tua mereka'.

Tidak terungkap dengan jelas dalam UUD RIS itu, apa yang menjadi argumen politis-ideologis apalagi argumen teologis keagamaan, sehingga pindah agama diperbolehkan. Belum diketahui, apakah kelompok nasionalis yang menyetujui UUD RIS itu mengacu pada argumen Hak Asasi Manusia (HAM) universal, dan kelompok Islam yang menyetujuinya merujuk pada ayat lâ ikrâh fî al-dîn.

Namun, lepas dari itu, ide kebebasan beragama dalam UUD RIS 1950 itu tercermin dalam memori kolektif umat Islam Indonesia, sehingga sampai sekarang publik Islam Indonesia tidak pernah mengriminalkan orang Islam yang pindah agama. Ormas Islam besar seperti NU dan Muhammadiyah tidak pernah mengajukan klausul dalam RUU KUHP untuk menetapkan tindakan keluar dari suatu agama sebagai tindakan kriminal. MUI yang dikenal sebagai organisasi keislaman berhaluan konservatif pun berpandangan sama. Walaupun para pengurus MUI mengakui bahwa tindakan keluar dari Islam tidak diperbolehkan, mereka tidak juga ingin memasukkannya ke dalam pasal penodaan agama dalam RUU KUHP sekarang.

49 Sebagian pihak menilai bahwa UUD RIS adalah konstitusi yang paling maju yang pernah dimiliki bangsa Indonesia dalam hal jaminan kebebasan beragama. Lihat Ahmad Suaedy, et al., Islam, Konstitusi, Hak Asasi Manusia: Problematika Kebebasan Beragama, dan Berkeyakinan di Indonesia (Jakarta: The Wahid Institute, 2009), 37. 


\section{Penutup}

Tulisan ini menyimpulkan: Pertama, pendapat yang menyatakan bahwa ayat lâ ikerahb fì al-dîn telah di-naskh ayat perang tidak mendapatkan sokongan argumen yang kuat. Sebab, kebebasan beragama adalah pokok (usîh), sementara perang itu adalah cabang (furû́). Kedua, argumen ulama yang menjadikan ayat lâ ikerâh fî al-dîn sebagai dasar kebebasan beragama lebih kukuh ketimbang argumen ulama yang menolak kebebasan beragama. Sayyid Qutb yang pendapat-pendapatnya kerap menjadi rujukan kelompok fundamentalis Islam pun berkata tentang tidak dibolehkannya pemaksaan dalam soal agama, termasuk memaksa orang lain untuk masuk Islam.

Mayoritas para mufassir cenderung menarik pengertian ayat lâ ikerâh fî al-dîn pada tidak bolehnya seseorang dipaksa masuk Islam. Dengan perkataan lain, pemahaman para ulama terhadap ayat tersebut tidak berlanjut pada pengertian dibolehkannya seseorang keluar dari Islam. Berbeda dengan pandangan mayoritas ulama tersebut, Jawdat Saî̀d dan Jamâl al-Bannâ berkata bahwa ayat lâ ikrâh fî al-dîn bukan hanya memberi ruang kebebasan untuk masuk pada suatu agama, melainkan juga untuk keluar dari suatu agama, tidak terkecuali keluar dari agama Islam. Penafsiran Jawdat Sa îd dan Jamâl al-Bannâ itu merupakan contoh penafsiran inovatif yang ditawarkan para pemikir Islam kontemporer untuk menuntaskan ide kebebasan beragama dalam Islam yang hanya berbentuk kebebasan masuk Islam dan belum bermakna kebebasan keluar dari Islam.

Namun, pandangan dua pemikir terakhir itu bukanlah tafsir mainstream ayat la ikrâha fí al-dîn. Ketiga, dalam konteks keindonesiaan, Nurcholish Madjid dan Abdurrahman Wahid adalah dua ulama progresif yang mendukung penuh kebebasan beragama. Bukan hanya kebebasan untuk masuk melainkan untuk keluar dari Islam. Sementara ketentuan fiqh yang menghukum bunuh orang murtad, menurut Gus Dur dan Cak Nur, harus diubah. Di samping merujuk argumen HAM, Cak Nur menggunakan argumen quranik (lâ ikrâh fî̀ al-dîn) untuk menolak hukum bunuh bagi murtad. Bagi keduanya jelas, Islam mendukung kebebasan beragama secara penuh. Pendapat dua ulama ini tidak terasa asing karena dalam UUD RIS telah disebutkan bolehnya seseorang untuk keluar dari suatu agama sebagai bagian dari hak yang melekat pada setiap orang. 


\section{Daftar Rujukan}

Abdalla, Ulil Abshar. Menyegarkan Kembali Pemikiran Islam: Bunga Rampai Surat-surat Tersiar. Jakarta: Nalar, 2007.

Alûsî (al), Shihâb al-Dîn Mạ̣mûd b. 'Abd Allâh al-Ḥusaynî. Rûh alMa'ânî fî̀ Tafsîr al-Qur'ân al-Až̃im wa al-Sab' al-Mathânî, Vol. 2. Kairo: Dâr al-Hadîth, 2005.

'Arabî (al), Ibn. Aḥkâm al-Qur'ân, Vol. 1. Beirut: Dâr al-Fikr, t.th.

'Âshûr, Muhammad al-Tâhir b. al-Taḥîr wa al-Tanwîr, Vol. 3, dan Vol.

5. Tunis: Dâr Suhnun li al-Nashr wa al-Tawzî‘, t.th.

al-Jawi, Muhammad Nawawi. Marah Labidz, Vol. 1. Indonesia: Dâr Ihyâ̂' al-Kutub al-'Arabîyah, t.th.

ash-Shiddieqy, Teungku Muhammad Hasbi. Tafsir al-Qur'an al-Majid An-Nuur, Vol. 1. Semarang: Pustaka Rizki Putra, 2000.

Bannâ (al), Jamâl. Tafnîd Da'wâ Hadd al-Riddah. Kairo: Dâr al-Fikr alIslâmî, 2006.

Bayḍ̂âî (al), Nâṣir al-Dîn Abû Saî̀d 'Abd Allâh b. 'Umar b. Muhammad al-Shîrâzî. Anwâr al-Tanzîl wa Asrâr al-Ta'wîl, Vol. 1. Beirut: Dâr al-Fikr, 1996.

Ghazali, Abd Moqsith. Argumen Pluralisme Agama. Depok: KataKita, 2009.

Jâr Allâh, Abû al-Qâsim Mạ̣mûd b. 'Umar b. Aḥmad alZamakhsharî. al-Kashshâf 'an Haqû̉iq al-Tanzîl wa 'Uyûn al-Aqâwil fî̀ Wujûh al-Ta'mîl, Vol. 1. Mesir: Dâr Mișr, t.th.

Jamâl (al), Muhammad 'Abd al-Mun'im. al-Tafsîr al-Farîd li al-Qur'ân alMajid. Kairo: Majma' al-Buhûth al-Islâmîyah, 1970.

Kathîr, Ibn. Tafsîr al-Qur'ân al-Ag̨im, Vol. 1. Beirut: Dâr al-Fikr, 1999.

Khâzin (al), 'Alâ' al-Dîn. Lubab al-Ta'wîl fî Ma'ânî al-Tanqî́l, Vol. 1. t.t.: Dâr al-Fikr, t.th.

Madjid, Nurcholish. Pintu-pintu Menuju Tuban. Jakarta: Paramadina, 1995.

----. Demi Islam, Demi Indonesia. Jakarta: Paramadina, 1999.

----- Islam, Kemodernan, dan Keindonesiaan. Bandung: Mizan, 2008.

Monib, Mohammad, dan Bahrawi, Islah. Islam, dan Hak Asasi Manusia dalam Pandangan Nurcholish Madjid. Jakarta: Kompas-Gramedia, 2011. 
Qâsimî (al), Jamâl al-Dîn. Mahâasin al-Ta'wîl, Vol. 2. Kairo: Dâr alHadîth, 2003.

Qurțuîi (al), Abû 'Abd Allâh Muḥammad b. Aḥmad b. Abî Bakr. alJâmi' li Aḥkâm al-Qur'ân, Vol. 2. Kairo: Dâr al-Ḥadîth, 2002.

Quṭb, Sayyid. Fî Zilâl al-Qur'ân, Vol. 1. Kairo: Dâr al-Shurûq, 2007.

Râzî (al), Fakhr al-Dîn. Mafâtih al-Ghayb, Vol. 4, dan Vol. 7. Beirut: Dâr al-Fikr, 1995.

Riḍâ, Akram. al-Riddah wa al-Hurriyah al-Dîniyah. t.t.: Dâr al-Wafâ, 2006.

Riḍ̂a, Muhammad Rashîd. Tafsîr al-Qur'ân al-Hakîm, Vol. 3. Beirut: Dâr al-Kutub al-'Ilmîyah, 1999.

Saî̀, Jawdat. Lâ Ikrâh fì al-Dîn: Dirâsât wa Abḥath fî̀ al-Fiker al-Islâmî. Damaskus: Markaz al-'Ilm wa al-Salâm li al-Dirâsât wa al-Nashr, 1997.

Sha'rawî (al), Muhammad Mutawallî. Tafsir al-Sha'rawn̂, Vol. 2. Mesir: Majma‘ al-Buhûth al-Islâmîyah, 1991.

Shihab, M. Quraish. Tafsir al-Misbah: Pesan, Kesan, dan Keserasian alQur'an. Jakarta: Lentera Hati, 2009.

Suaedy, Ahmad, et al. Islam, Konstitusi, Hak Asasi Manusia: Problematika Kebebasan Beragama, dan Berkeyakinan di Indonesia. Jakarta: The Wahid Institute, 2009.

Suyûtị̂ (al), Jalâl al-Dîn. al-Itqân fî̀ 'Ulûm al-Qur'ân, Vol. 1. Kairo: Dâr al-Fikr, t.th.

Tabarî (al), Ibn Jarîr. Jâmi' al-Bayân fî Ta'mîl al-Qư'ân, Vol. 3. Beirut: Dâr al-Kutub al-'Ilmîyah, 1999.

Ṭabâtabâ‘̂̀ (al), Muhammad Husayn. al-Mî̃ân fî Tafsîr al-Qur'ân, Vol. 2. Beirut: Mu’assasat al-'Âlamî li al-Maṭbû́ât, 1991.

Tim Penyusun Kamus Pusat Pembinaan, dan Pengembangan Bahasa. Kamus Besar Bahasa Indonesia. Jakarta: Balai Pustaka, 1996.

Wahid, Abdurrahman. Islamku, Islam Anda, Islam Kita. Jakarta: The Wahid Institute, 2006.

Zuhaylî (al), Wahbah. al-Tafsîr al-Wasît, Vol. 1. Beirut: Dâr al-Fikr, 2000. 